\title{
Waters recede, damage estimates soar
}

With this issue, California Agriculture introduces Outreach News, a section that will highlight news developments in or related to UC Cooperative Extension programs.

Torrential storms during New Year's week poured up to 25 inches of rain on the foothills of Northern and Central California. Unprecedented runoff combined with the release of stored water created conditions

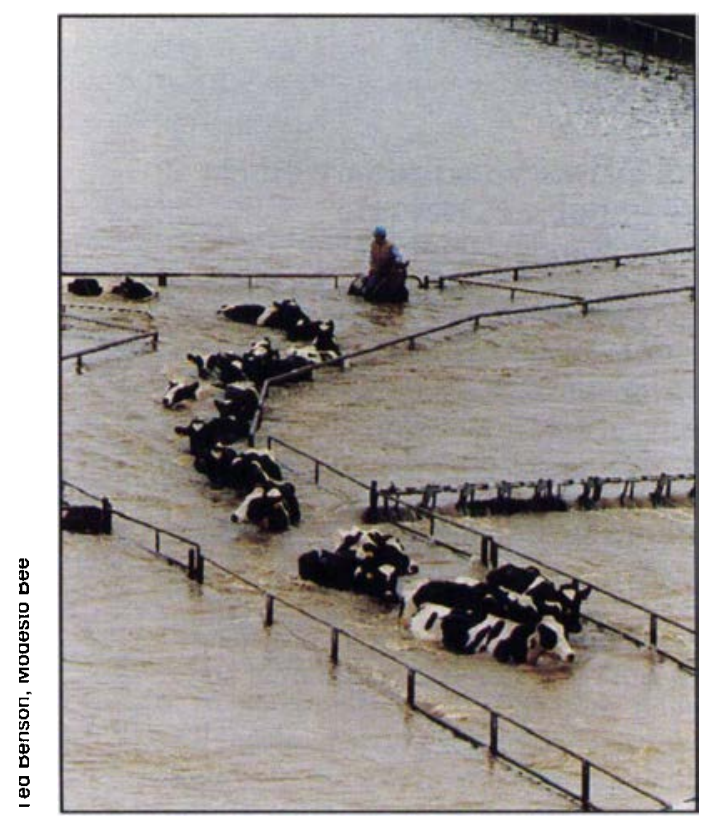

Gene Roberts of Merced works to rescue a dairy herd stranded by the flooding Tuolumne River west of Modesto. damage. that led to numerous levee breaks along the Sacramento and San Joaquin River systems. The California Department of Food and Agriculture (CDFA) estimated the resulting agricultural damage at $\$ 245$ million by the end of January.

Rushing rivers overflowed their banks and busted levees, drowning livestock, submerging orchards and vineyards and washing away field crop plantings.

Yuba County topped the list, reporting more than $\$ 74$ million in damages and Stanislaus County was second, with a $\$ 37$ million loss. Infrastructure damage, along with the impact of flooding on land, private levees, farm equipment, buildings and irrigation systems, appears to be the most significant, with $\$ 124$ million in reported

According to county reports submitted to CDFA, 59,000 acres of crops have been lost and 95,000 acres damaged by the rain and flooding, an estimated loss of $\$ 89$ million. Walnuts posted the highest loss, $\$ 16.9$ million; followed by livestock and dairy, $\$ 16.5$ million; and nursery products, \$16 million. Other crops taking substantial hits include alfalfa, \$15 million; winegrapes, $\$ 13.8$ million; wheat, $\$ 8.1$ million; plums and prunes, $\$ 6.1$ million; and peaches, $\$ 5.8$ million.

UC is organizing a Flood Task Force to mobilize UC's research and educational outreach expertise to assist Californians in dealing with impacts of the recent floods. UC President Richard
Atkinson has named Reg Gomes, vice president, agriculture and natural resources, and Robert Shelton, vice-provost for research programs, to head the task force. One goal of the task force is to develop a research agenda focusing on how to minimize the economic and physical impacts of future floods on California. Another goal is to review flood information developed by UC Cooperative Extension and examine ways to include the accessibility of these materials to the public and disaster relief agencies in times of emergency.

In addition, Gomes and Shelton will serve on a Flood Emergency Action Team (FEAT) appointed by Governor Wilson. FEAT issued a report on Feb. 10 with recommendations for expediting disaster loan payments and coordinating flood recovery activities, including draining submerged agricultural lands and repairing levees. A second report scheduled for completion by June 10 will address longer term issues including levee maintenance, how to better handle flood waters (especially storage), longrange weather forecasting, changes in flood plain management, and a comprehensive look at the flood plans for the Sacramento, American and San Joaquin river systems.

From delivering disaster-recovery information to simply being good neighbors, Cooperative Extension has already helped fellow Californians cope with the aftermath of the floods.

Many animals died in flash floods and levee breaks in the Yuba City, Manteca and Modesto areas, creating a potential public health hazard. Dairy and livestock advisors advised ranchers about burying dead livestock and suggested ways of preventing behavioral changes and mastitis, botulism and other diseases that can occur as a result of flooding conditions or after herds are mingled. Marit Arana, area dairy advisor, said that cows in 22 herds had died or suffered from disease as a result of the floods in Northern California. One herd in Marysville lost 230 cows to hypothermia.

Sutter-Yuba counties farm advisor Janine Hasey is helping local officials assess crop damage. Several thousand acres of tree crops, mainly walnuts, prunes, peaches and pears, were still under water in February. Many grow- 
ers have not been able to assess the damage to their trees. Except for trees that are visibly down or broken, the effects from the flooding - such as problems from waterlogging or phytophthora diseases - may not be determined until after summer. Some problems, such as phytophthora root rot on walnut may cause tree decline over several years, Hasey said.

To anticipate the effects of the flooding on orchards, Hasey, who was an advisor during the 1986 flood, consulted growers who endured the big floods of 1955 and 1986 . Whole peach orchards died in 1955; if the same thing happens this year, the loss, including lost income, could be over $\$ 20,000$ an acre, she said. Walnut and prune trees are also vulnerable; in 1986, prunes and walnuts died from aerial phytophthora where water had sat for several weeks after the February flood.

Flooding was particularly severe around Manteca and Mossdale. San Joaquin County extension staff distributed photocopied flood materials to homeowners and growers. County director Gary Johnston said he and his staff are also helping farmers deal with water-logged soils, moldy homes and crops, damaged feed and replanting schedules.

Millions of honey bees drowned in the flood. UC Davis apiculturist Eric Mussen thinks between 10,000 and 20,000 bee colonies have been lost. Loss estimates vary widely and other esti- mates are much higher. He says the extent of the impact probably won't be known until after almond pollination. Some individuals lost large numbers of bees. One beekeeper had 1,800 bee boxes in an area that flooded. The area is still off limits, so the beekeeper doesn't know how many of them survived. The cost of replacing a colony is between $\$ 60$ and $\$ 100$ and few beekeepers have flood insurance.

Although California growers normally use about 800,000 bee boxes to pollinate their 410,000 acres of almond trees, Mussen doesn't expect a shortage. "We still have neighbors in Arizona, Nevada and Idaho who didn't bring their bees this year, but if there is a big demand some may decide it's worthwhile to come," he adds.

Weather may be the real factor in whether there is a good almond crop this year. "We didn't get a good chill this year and bloom is straggly," Mussen says, which means varieties that cross-pollinate may not release their pollen at the same time.

Another flood-related setback is that orchards may be too muddy to drive through to distribute the bees; the boxes may have to be set along the edges of orchards.

- Editor

\section{How UC helped}

UC has generated a number of publications for coping with flooding; most are available at county offices and some are offered in languages other than English.

Sutter-Yuba counties extension director Jack Williams and two employees assembled floodcleanup information and began distributing the packets. The 44-page packet included instructions on how to clean homes, appliances, furniture, clothes, cars and trucks; how to salvage family papers; and how to ensure safe food and water.

UC veterinarian John Kirk summarized each county's regulations for dairy and livestock advisors, which they used to advise ranchers about burying dead livestock. Kirk also disseminated a tip sheet for dairy producers describing problems to look for in cows that had been moved or that weren't milked during the deluge.

The Sonoma County Cooperative Extension office has a 30-page handbook, "Cleaning Up after Sonoma County's Flood," which was de-

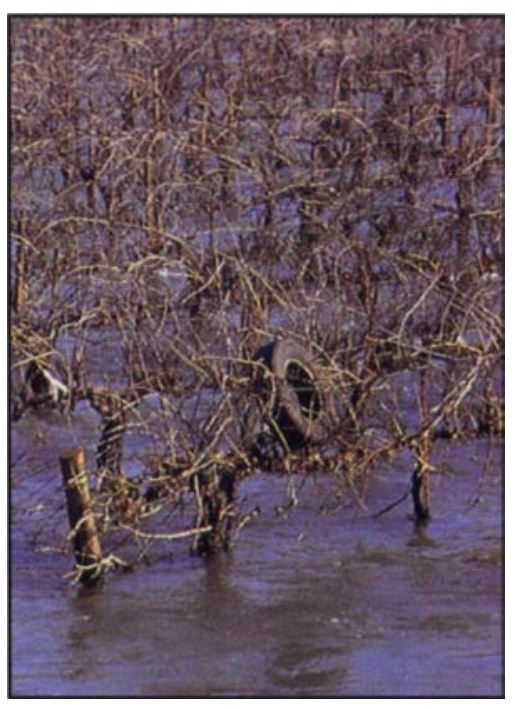

Gov. Wilson has provided $\$ 8.25$ million in immediate disaster relief to clean up damaged areas. veloped from information prepared for victims of the Midwest's 1993 flood. The six issues of "Ready or Not: An Emergency Preparedness Newsletter" include "Planning for an Emergency," "Safety," "Food and Water," "Considerations for Children," "Finance and Insurance," and "Setting Clean-up Priorities."

Five handouts with clean-up, health and safety tips, Sonoma County's flood packet and a brochure on how to avoid scams that often pop up after disasters are offered in Spanish. The Farm Safety Program issued special English and Spanish editions of their newsletter on flood topics.

DANR's Spanish Broadcast and Media Services unit developed a 30-part series of public service announcements for Spanish-speaking Californians on disaster prevention and recovery. The Small Farm Program is helping farmers obtain emergency funds and is providing technical information to restore production. 